\title{
骨髄の呼吸解糖作用に関する研究
}

第 3 編

正常家兔骨䯣の組織呼吸作用飞及任す

各種抗白血病剤の影響

同山大学医学部平木内科教室（主任 : 平木 潔教授）

大学院医学研究科 真 田 浩

[昭和 34 年 8 月 8 日受稿]

\begin{tabular}{|c|c|}
\hline \multicolumn{2}{|l|}{$\cdot$} \\
\hline 第 1 章 & 言 \\
\hline \multicolumn{2}{|c|}{ 第 2 章 実験方法 } \\
\hline \multicolumn{2}{|c|}{ 1）実験動物並びに骨能切片の調製 } \\
\hline \multicolumn{2}{|c|}{ 2) 浮游液 } \\
\hline \multicolumn{2}{|c|}{ 3）各種抗白血病剂液 } \\
\hline \multicolumn{2}{|c|}{ 4）呼吸值測定方法 } \\
\hline \multicolumn{2}{|c|}{ 第 3 章 実験线績 } \\
\hline 第 1 節 & $\begin{array}{l}\text { 正常家鬼骨髄の呼吸值及ぼ Nitro- } \\
\min \text { 添加の影饉 }\end{array}$ \\
\hline 第 2 節 & 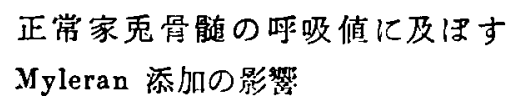 \\
\hline 箱 3 節 & 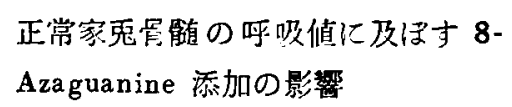 \\
\hline
\end{tabular}

\section{第1章 楮言}

近年恶性原厡に対する関心か!强まつて来万と其に， 恶性腫㻛に対する治療方法は著るしい進少を遂げ， なかんなく化学療法による治療は目覚ましい発展を

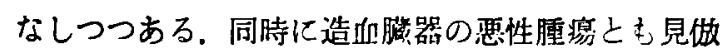
されていろ白血病に齐する治療もその様相を一变し た.さて白血病の治療は先ず1865年 Lissaur ${ }^{111}$ ) 亿 よつて吪素剂犬゙用いられたのに始まり，1900年代に はレントゲン線照射による治療が広く行われ，特に 慢性骨髄性白血病に対しては可成りの効果を収めた。 1946年に至り Paterson117) 等は Urethaneが有効で あることを認め，以後陸続として抗白血病剂の出現 を見るに至つた。即ち1948年 Farber 等83により Aminopterin 等の葉酸拮抗物質が急性白血病に有 効であるととが浔められ，1949年から1951年にかけ $\tau$ Pearson118), Farber82), Dameshek ${ }^{76)}$, Rosen-
第 4 節 正常家兔骨植の呼吸值に及ぼす6Mercaptopurine 添加の影響

第 5 節 正常家兔骨䯙值の呼吸值に及ばすPrednisolone 添加の影響

第6 節 正常家克骨髄の呼吸值に及ほすす ACTH 添加の影蚃

第 7 節 正常家兔骨韨の呼吸做に及ほす Actinomycin $\mathrm{C}$ 添加の影瘖

第8節 正常家兔骨榷の呼吸值に及はす Carzinophilin 添加の影響

第 4 章 総括並びに考按

第 5 章 結 論

thal125) 等により急性白血病に ACTH, Cortisone 等の Hormone 剂か：有效でることが報じられ， 1951年に石捨102) 及ご吉田によりとりあげられた Nitrogen mustard-N.Oxide が慢性骨能道性白血病に 対して著効を示すてとが明らかになり広く用いられ る様になつた。一方 Karnofsky105)(1951)により TEM が, Shayl31) (1952)により Thio-TEPAが慢 性白血病に良効をむたらすととが報じられ，又 Hitching 999100), Elion 等80）により発見され, Burchenal (1953) 等69)により白血病に著效を示す ととが楒められた $6 \mathrm{MP}$ あ広く使用せられており, 1953年には Haddow 等94)により Myleran が顆粒 白血球を特に抑制することが注目され，Galton年等 により慢性骨髄白血病に用いられる様になり，同年 Demecolcin が Bock 等66) 亿より慢性骨榷性白血 病に有効であることが報じられた。

てれらに加うるに最近に至つては抗生物質も続な 
と登場し Hackmann93)により Actinomiycin C の

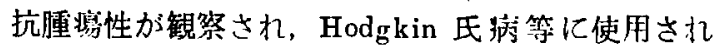
ており，1954年秦98）は抗隀煬性物質として Carzinophilin を発見し更に Ellion 等81)により Azaserine が急性白血病に用いられ，その他に屯数多くの抗生 物質が試験されつつある。乙れ等の薬剂は覀性腫痬 に対して障害的に作用するか，生体に対しても毒性 を有し，ただその程度に差が存するのみである．化 学療法剂についての悪性腫瘍に対する作用に関して は, 結節性腫場或いは腹水性腫瘍等を用いて形態的 或いは機能的な観察がなされ，又置髄に及ぼす影響 についても形態学的検討がなされているが, 機能的 方面の研究は少なく特にエネルギー代謝に関する観 察は永井36) によりウレタン, ナイトロミン投与家 克についての呼吸解糖值の検索が行われている他 Warren153）により重砒酸カリについて家兔胃髄へ の添加実験が行われ，酸素消热量を低下させること が報じられていていうが，抗白血病剂についての広 汎な研究は行われていない，著者は上記楽剂の中か ら現在最む屡々用いられているものとして Nitromin, Myleran, 6 MP, Prednisolone, ACTH, Carzinophilin を選び，てれに Hodgkin 氏病に卓 効を示す, Actinomycin C と Purine 代謝拈抗物 質である 8-Azaguanine を併せて，てれら8種類の 薬剂について，之れ等を便用した場命における骨髄 機能の変化をエネルギー代謝の面から窺うとともに， 白血病骨䯣に対する楽剂の効果を代謝面から観察す る Screening test の場合の参考!供する為に War-

3）各種抗白血病剂液

$\begin{array}{lr}\text { Nitromin } & 5 \times 10^{-1} \mathrm{~g} / \mathrm{dl} \\ \text { Myleran } & 10^{-1} \mathrm{~g} / \mathrm{dl} \\ \text { 8-Azaguanine } & 5 \times 10^{-1} \mathrm{~g} / \mathrm{dl} \\ \text { 6-IIP } & 25 \times 10^{-1} \mathrm{~g} \mathrm{dl} \\ \text { Prednisolone } & 1 \mathrm{~g} / \mathrm{dl} \\ \text { ACTH } & 10^{3} \mathrm{unit} / \mathrm{dl} \\ \text { Actinomycin C. } & 10^{-2} \mathrm{~g} / \mathrm{dl} \\ \text { Carzinophilin } & 25 \times 10^{4} \mathrm{unit} / \mathrm{dl}\end{array}$

になる様に $9.0 \mathrm{~g} / l$ 食塩水に上り溶液又は覞濁液 として調製した，上記の各種添加液 $0.3 \mathrm{cc}$ を $1.2 \mathrm{cc}$ の浮游液に添加することになるので添加後の終 末漕度は上述の濃度の $1 / 5$ となる。各種抗白血病 剂液の終末濃度に於ける $\mathrm{pH}$ を SHIMADZU pH METER Gu-1 No. 8300 により測定した成績は素 1 に示す通りである, btrg 検任計を用いて正常家兔罪䯣の呼吸作用に及

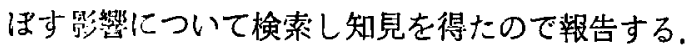

\section{第2章実験方法}

1）実験煙物並びに，具䯣切片の調彆

休重 $2 \mathrm{~kg}$ 内外の雄性白色家兔を 1 週間一定飼料 にて飼育し，環塃及び飼料に馿致せしぬた後末梢血 液を検查し正常であることを確めた後使用した，家 兔の頭頂部を強打し，速やかに両側頸部動静脈を切 断，潟血した後，股及び䐂関節を離断して車側大腿 骨を取り出し，上端は主栄養動静脈穿入部，下端は 骨端線より $3 \mathrm{~mm}$ 上方で内骨膜を損傷せぬ程度に 惄質に割を入れ，外面を清拭して両骨端を離断し予 め用意してある重曹を含まないリンゲル液中に骨髄 をとり出し，この円柱状骨䯣は教室清水22）の方法 によりグレーフェ氏線状小を用いて厚さ $0.5 \mathrm{~mm}$ 以下の所謂限界切与厚内の切片を作蔽する.

2) 浮游液

各種抗白血病剤の添加の際に生ずる $\mathrm{pH}$ の変化を 僅微にす万為に次に示す如く食塩燐酸塩液を用いそ の $\mathrm{pH}$ は教室清水22)の成繢より家兔骨䯣呼吸値 の最高値を示す $\mathrm{pH}=7.4$ とした. Lison'10)に從い $\mathrm{MI} / 2$ 第 2 燐酸ソーダ 808 と $\mathrm{M} / 2$ 第 1 燐酸力リ 192 の 割合の䌅衝液を調製し $9.0 \mathrm{~g} / l$ の食塩液 $240.0 \mathrm{cc}$ と 燐酸楥唃液 $10.0 \mathrm{cc}$ を混じ調製後 SHIMADZU pH METER MODEL Gu-1No. 8300 により $\mathrm{pH}=7.4$ であることを確認した。

$$
\begin{array}{rr}
5 \times 10^{-2} \mathrm{~g} / \mathrm{dl} & 5 \times 10^{-3} \mathrm{~g} / \mathrm{dl} \\
10^{-2} \mathrm{~g} / \mathrm{dl} & 10^{-3} \mathrm{~g} / \mathrm{dl} \\
5 \times 10^{-2} \mathrm{~g} / \mathrm{dl} & 5 \times 10^{-3} \mathrm{~g} / \mathrm{dl} \\
25 \times 10^{-2} \mathrm{~g}^{\prime} \mathrm{dl} & 25 \times 10^{-3} \mathrm{~g} / \mathrm{dl} \\
10^{-1} \mathrm{~g} / \mathrm{dl} & 10^{-2} \mathrm{~g} / \mathrm{dl} \\
10^{2} \mathrm{unit} / \mathrm{dl} & 10^{\mathrm{unit} / \mathrm{dl}} \\
10^{-3} \mathrm{~g} / \mathrm{dl} & 10^{-4} \mathrm{~g} / \mathrm{dl} \\
25 \times 10^{3} \mathrm{unit} / \mathrm{dl} & 25 \times 10^{2} \mathrm{unit} / \mathrm{dl}
\end{array}
$$

4) 測定方法

㭘圧は藤田48）の著害に従いWarburg 直接法に よつた. 表 2 に示す如く浮游液, 添加液, 苛性力リ液, 骨髄切片を充填した後検圧用円錐容器を検圧計に接 続し，純酸素を通じた後 $38^{\circ} \mathrm{C}$ 恒温槽中で毎分 120 回，振幅 $5 \mathrm{~cm}$ の条件で振望した. 15分間の予備振 滥の後検圧計の読みを閒始し10分每に30分迄のガス 
圧の変化を計測する，30分目の検圧直後に側室中の 添加液を主室に移し側室内を 2 回主室内の液で洗つ た後振溫を続け，20分後より10分毎に60分迄計測す る. 検圧終了後対照容器内の内容を第 1 編に記載し たと同様の方法により無脂肪乾燥重量として秤量し 対照の呼吸值をQ02 として求めた，抗白血病剂考添 加した場合の Q02 は添加前30分間の圧の変化之添加 後の圧の変化と対照の Q02 加ら簡単に計算によつて 求めることが出来, 各容器についての無脂肪乾燥重 量湘定の煩雑を除き得ると共に，重㫜計測その佔に 伴う点差を除外し得る利点を有する，Q02 の算出は 次式に往つた。

側室液添加前30分の任の変化を対照例 $\mathrm{h}_{1}$, 楽剂 添加例 $\mathrm{H}_{1}$, 側室液添加後の圧の変化を対照例 $\mathrm{h}_{2}$, 菒剂添加例 $\mathrm{H}_{2}$, 容器恒数を対照例 $\mathrm{k}$, 葲剂添加例 $\mathrm{K}$, 無脂肪乾燥重量を対照例 $\mathrm{w}$ ，薬剂添加例 $\mathrm{W}$ （未知）とすれば

$$
\frac{\mathrm{h}_{1}}{\mathrm{w}}=\frac{\mathrm{H}_{1}}{\mathrm{~W}}, \quad \mathrm{~W}=\frac{\mathrm{H}_{1} \mathrm{w}}{\mathrm{h}_{1}}
$$

従つて

$$
\mathrm{Q}_{2}=\frac{\mathrm{KH}_{2}}{\mathrm{~W}}=\mathrm{K} \frac{\mathrm{h}_{1} \cdot \mathrm{H}_{2}}{\mathrm{H}_{1} \cdot \mathrm{w}}
$$

となる。

\begin{tabular}{|c|c|c|}
\hline 薬 剂 名 & 涻度 $(\mathrm{g} / \mathrm{dl})$ & pH \\
\hline Nitromin & $\begin{array}{l}10-1 \\
10-2 \\
10-3\end{array}$ & $\begin{array}{l}7.1 \\
7.3 \\
7.4\end{array}$ \\
\hline Myleran & $\begin{array}{l}2 \times 10^{-2} \\
2 \times 10^{-3} \\
2 \% 10^{-4}\end{array}$ & $\begin{array}{l}7.2 \\
7.4 \\
7.4\end{array}$ \\
\hline 8-Azaguanine & $\begin{array}{l}10-1 \\
10-2 \\
10-3\end{array}$ & $\begin{array}{l}7.9 \\
7.4 \\
7.4\end{array}$ \\
\hline 6-Mercaptopurine & $\begin{array}{l}5 \times 10^{-1} \\
5 \times 10^{-2} \\
5: 10^{-3}\end{array}$ & $\begin{array}{l}7.3 \\
7.3 \\
7.4\end{array}$ \\
\hline Prednisolone & $\begin{array}{l}2 \times 10^{-1} \\
2 \times 10^{-2} \\
2 \times 10^{-3}\end{array}$ & $\begin{array}{l}7.4 \\
7.4 \\
7.4\end{array}$ \\
\hline ACTH & $\begin{array}{r}2 \times 10^{2} \text { unit } / \mathrm{dl} \\
2 \times 10 \mathrm{unit} / \mathrm{dl} \\
2.0 \mathrm{unit} / \mathrm{dl}\end{array}$ & $\begin{array}{l}7.3 \\
7.4 \\
7.4\end{array}$ \\
\hline Actinomycin C & $\begin{array}{l}2 \times 10^{-3} \\
2 \times 10^{-4} \\
2 \times 10^{-5}\end{array}$ & $\begin{array}{l}7.5 \\
7.4 \\
7.4\end{array}$ \\
\hline Carzinophilin & $\begin{array}{l}5 \therefore 10^{4} \text { unit } / \mathrm{dl} \\
5 \times 10^{3} \text { unit } / \mathrm{dl} \\
5 \times 10^{2} \mathrm{unit} / \mathrm{dl}\end{array}$ & $\begin{array}{l}7.5 \\
7.5 \\
7.5\end{array}$ \\
\hline
\end{tabular}

表 1 各抗白血病劍液の $\mathrm{pH}$

表 2 容器内容

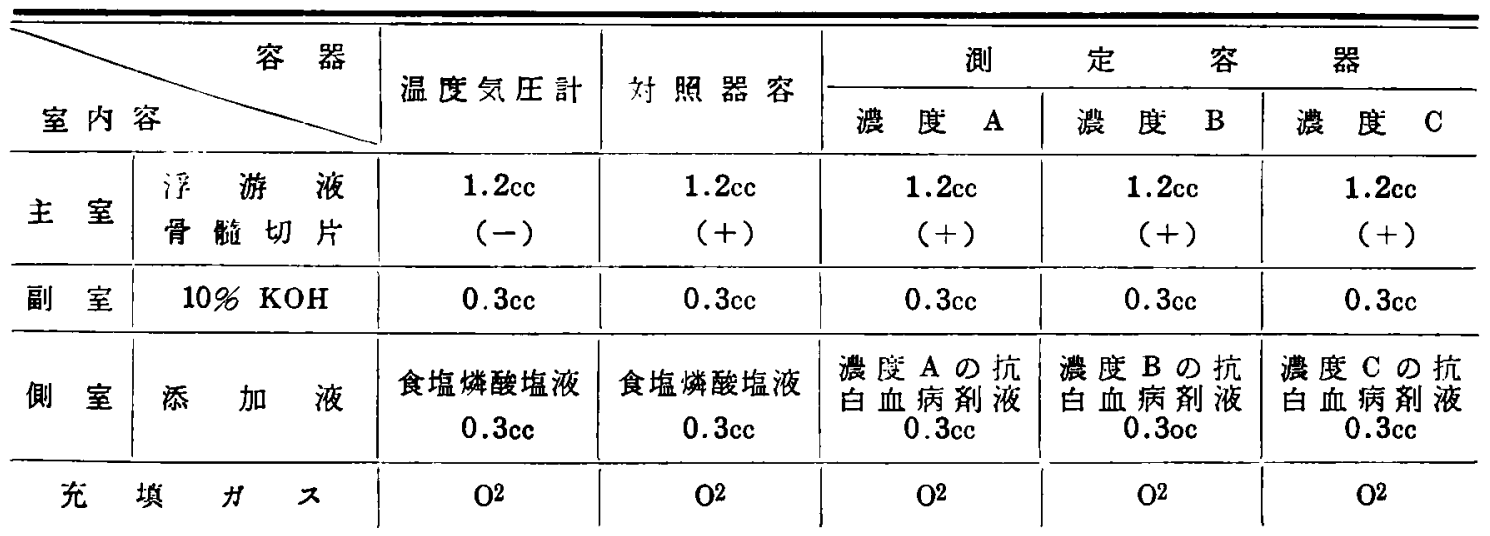

第3章 実 駼成績

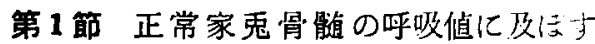
Nitromin 添加の影響

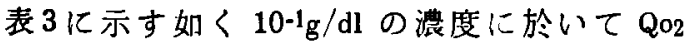
の平均値は対照に比し $35.9 \%$ の低下を示し, 全例とも減少している。ててれを推計学的に検
討すると $\mathrm{Fs}=20.85$ となり，2.5\%以下の危険 率で Q02 の低下は有然と認められた. $10-2 \mathrm{~g} / \mathrm{dl}$ の滞度では Q02 の平均檤は対照に比し5.096 の低下 を示すが個々の例をみると減少を示すのは 3 例で推 計学的にも Fs=1.07 て差は有意でない. $10^{-3} \mathrm{~g} / \mathrm{dl}$ の濃度では Qo2 の平均値は4.1\%の低下がみられる 
表 3 Nitrormin を添加した場合の正常家 鬼骨骴の呼吸値

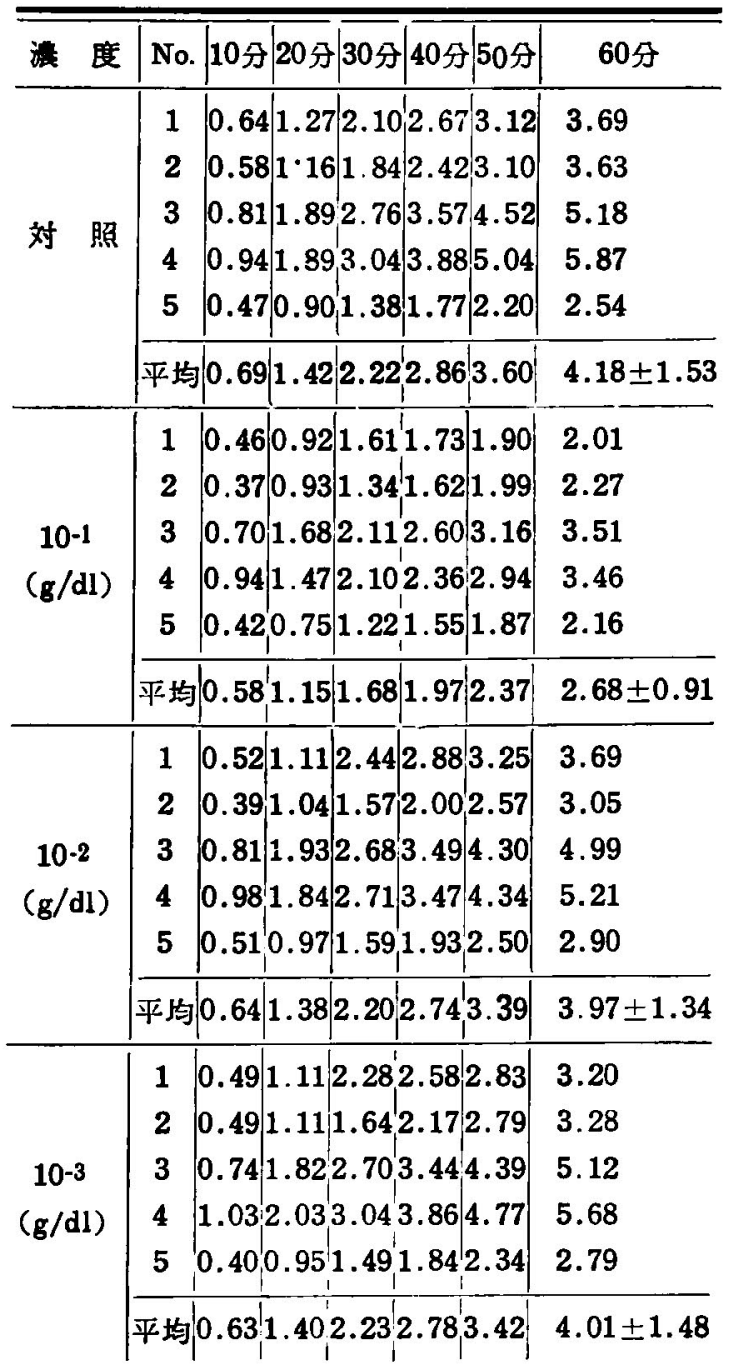

が個々の例では 1 例に增加をみるすのがあり， Fs= 1.74で有意の差を認めない.

毎10分酸素消頃量の時間的経過は図 1 の如く添加 後から漸次低下を示している. 又 $10.1 \mathrm{~g} / \mathrm{dl}$ の溄度 に於いては最初から低下か認められ時間の経過とと

图 1 Nitromin を添加した場合の敏10分 酸菜消費是の時間的経過

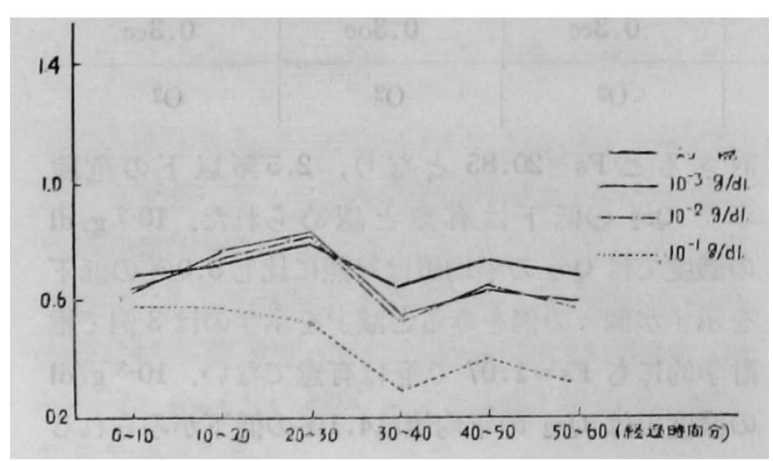

あに渐次著明になつている。

第2 節 正常家兔骨酭の呼吸値に及ばす Myleran 添加の影響

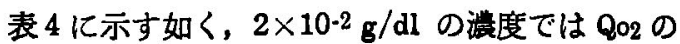
承均値は対照に比し $2.9 \%$ の艺進を示しているが，

表 4 Myleran を添加した場合の正常 家鬼骨髓の呼吸值

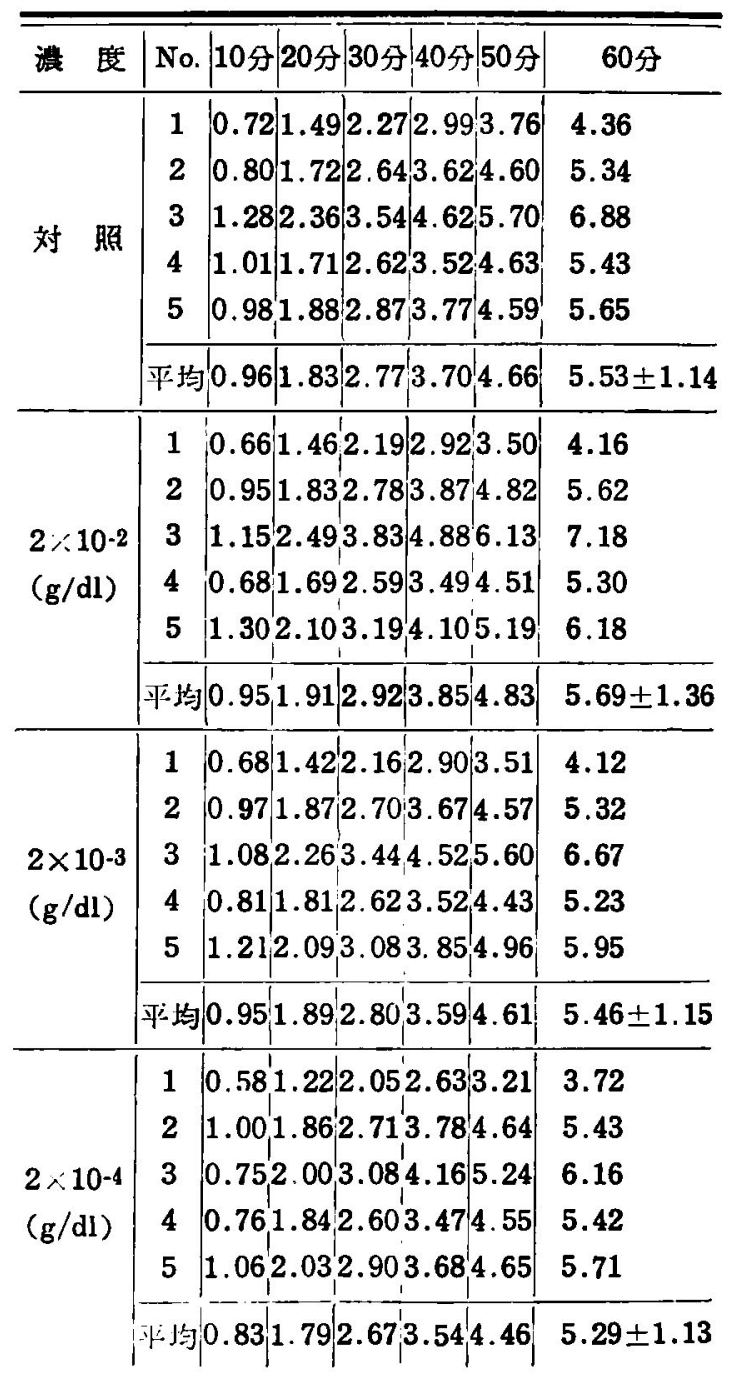

図2Myleranを添加した場合の每10分 酸菜消貲量の時間的経過

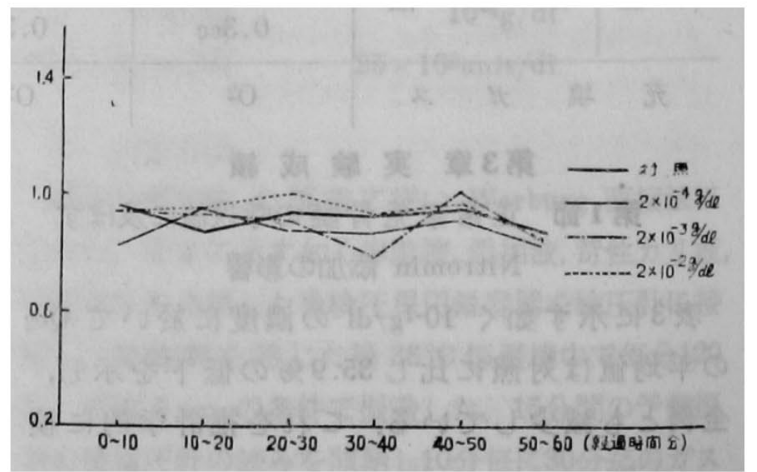




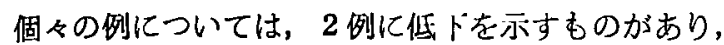
推計学的には，Fs=1.30で有芯の差はない， $2 \times$ $10^{-3} \mathrm{~g} / \mathrm{dl}$ の濃度でも対照との間に有意の差はなく， $2 \because 10^{-4} \mathrm{~g} / \mathrm{dl}$ の濃度では Qo2 の平均值は $4.3 \%$ の低 下を示しているが，個くの例については，2 例にお いて上昇を認めており，推計学的には $F s=1.85 て ゙$

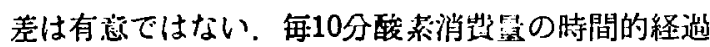
は図 2 の如く，各群とも対照と大差を認らない。

第3 節 正常家兔骨能伐 吸值に及ぼす

\section{8-Azaguanine 添加の影響}

表 5 亿示寸如く $10-1 \mathrm{~g} / \mathrm{dl}$ の濃度では Q02 の平均 值は2.4\%の增加を示しているが，個々の例では 1 例任下を認めており，推計学的にみると $\mathrm{Fs}=0.10$ で有意の差は存在せず, 又 10-2 $\mathrm{g} / \mathrm{d} 1$ の濃度でも Q02 の平均值は 6.096 の六進を示しているか，個々の例 では2 例低下を諗め推計学的には Fs $=1.38$ で埥

表 58 Azaguanineを添加した場合の正 常家鬼骨檤の呼吸値

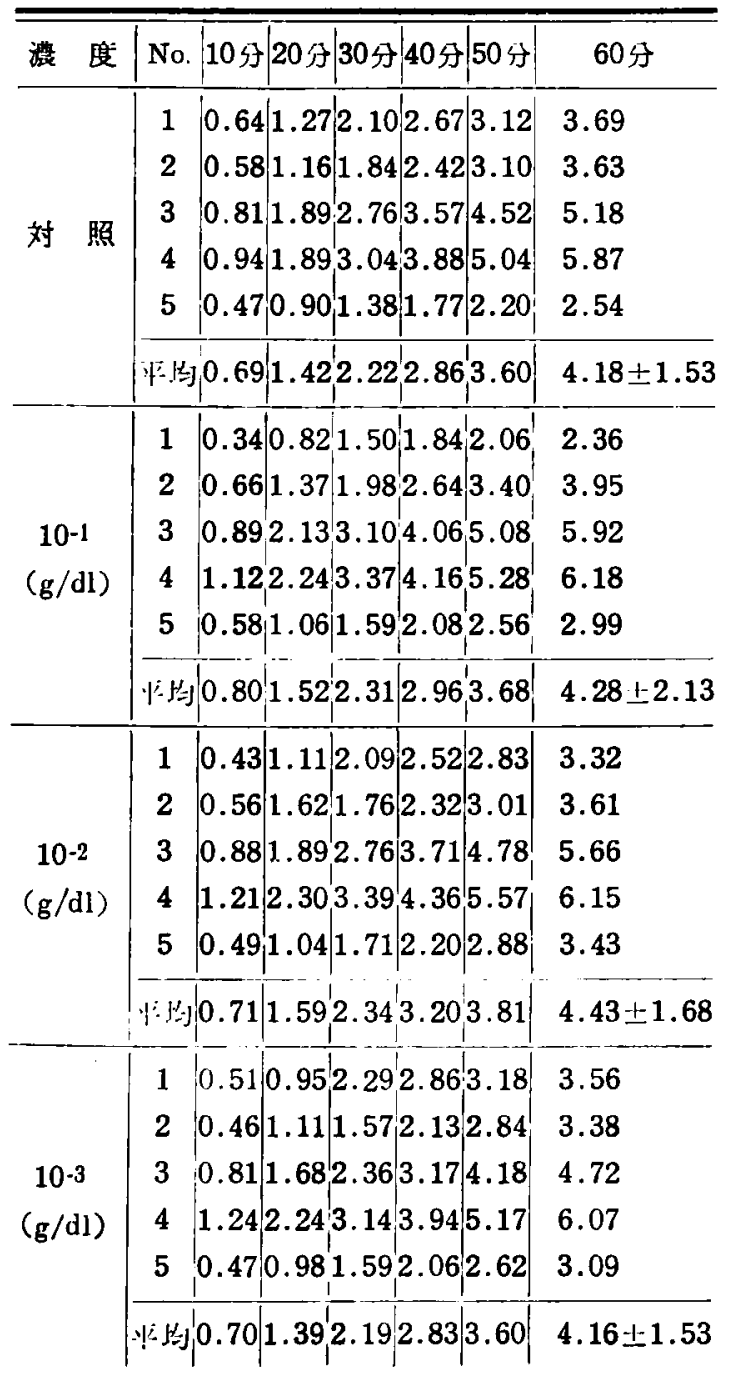

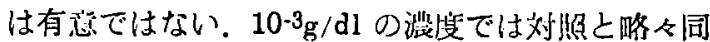
じ倬を示し勿論推計学的にも $F \mathrm{~s}=0.013$ で有意の

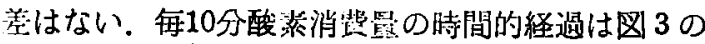
如く対照との間に差を認めなかつた。

図38-Azaguanineを添扣した場合の政

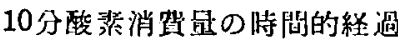

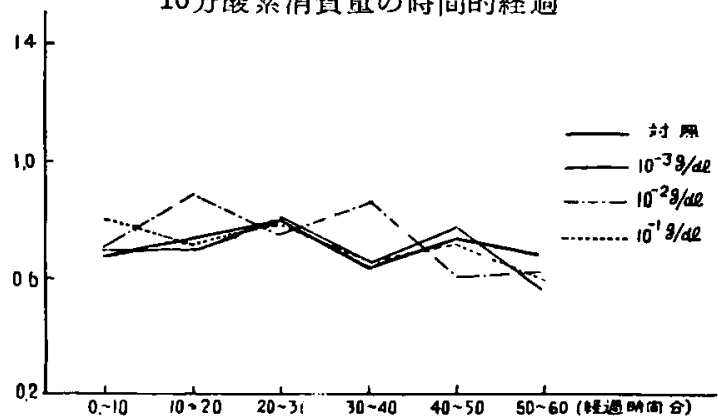

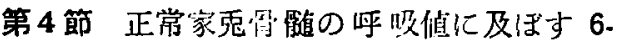
Mercaptopurine 添加の影響

表6に示す如く $5 \times 10^{-1} \mathrm{~g} / \mathrm{dl}$ の祳度に於いては

表 66 Mercaptopurineを浫㧈した場合の

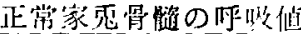

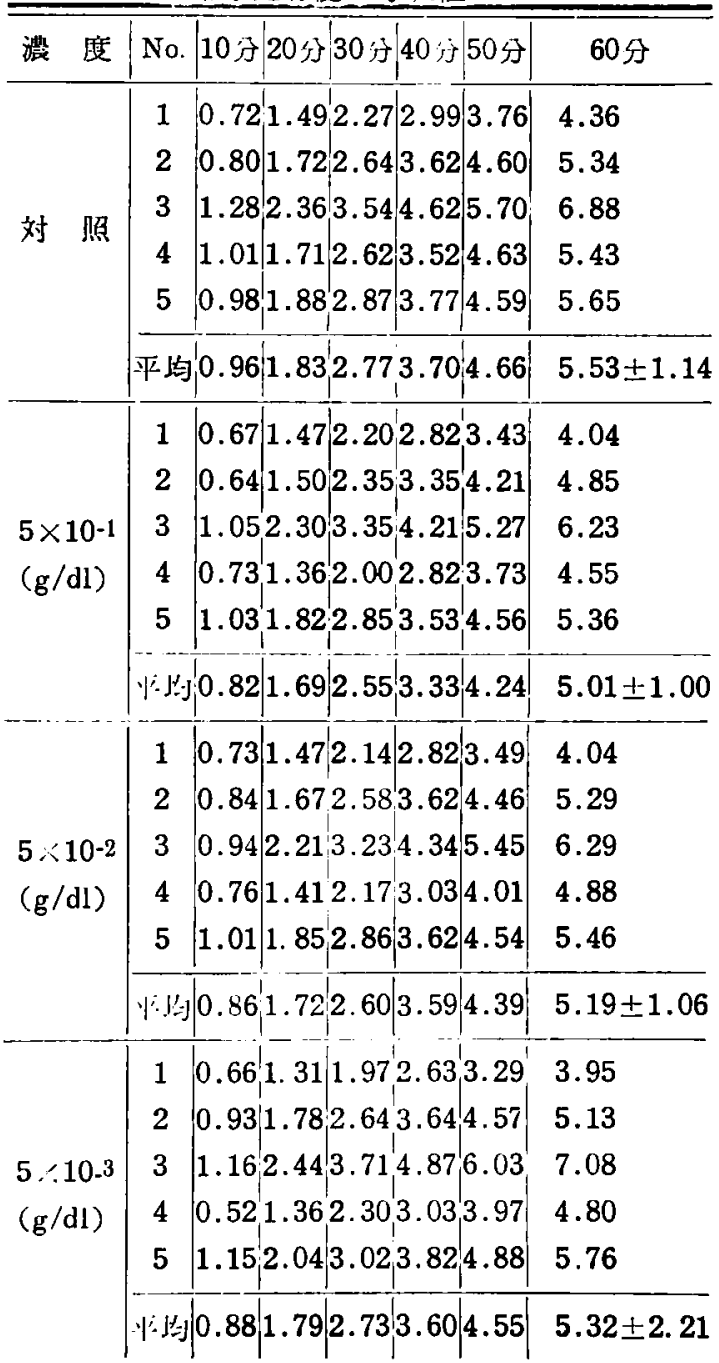


Q02 の曱均值は対照に比し9.496の低下を示してお

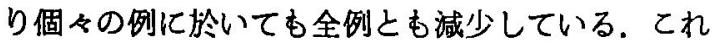
を推計学的に検討すると $\mathrm{F}_{3}=8.22$ となり，5\%以 下の他険率で Q02 の低下は有望と認められる，5× 10-2 g/dl の溶度に於いては Q02 の平均值は対照に 此し6.196の低下を示し，個々の例に於いても全例 に低下を認め，推計学的にみると， $\mathrm{Fs}=10.97$ で 5 \%以下の危険率で Q02 の低下は有意と判定される. $5 \times 10^{-3} \mathrm{~g} / \mathrm{dl}$ の荟度に於いては Q02 の平均値は3.8 \%の低下を示しているか，個々の例では Q02 の六進 を示すむのが 2 例であり，推計学的には $\mathrm{Fs}=1.51$ で有意の差は認められない，侮10分酸素消費量の時 間的経過は四 4 亿示す如く，高濃度の群が低いが時 間の経過による著明な変趿はみられない。

四46 NP を添加した場合の 毎10分酸素 消費量の時間的経過

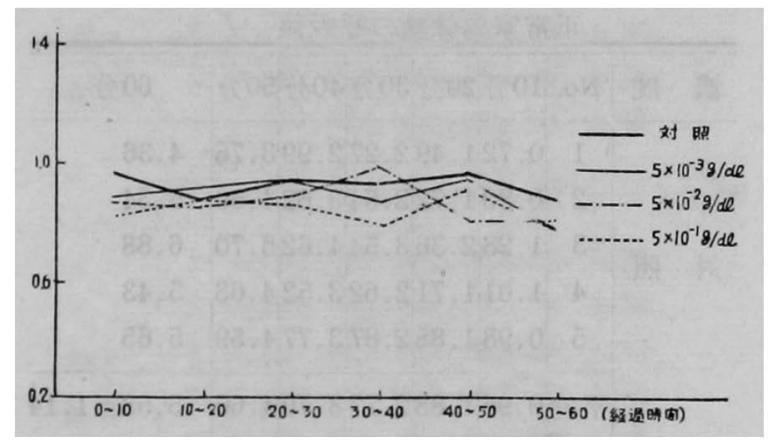

第 5 節 正常家兔骨髓の呼吸值に及ばす Prednisolone 添加の影嚮

婊 7 亿示す如く 2 10-1 $\mathrm{g} / \mathrm{dl}$ の濃度でQ02 の平 均倬は対照に比し34.4\%の低下を示し個々の例につ いても全例に於いて低下を認める．推計学的にみれ ば, Fs=60.60で 1 \%以以下危険率に於いて Q02 の 低下は有意である. $2 \times 10-2 \mathrm{~g} / \mathrm{dl}$ の洤度では Qo2 の 平均値は 5.6\% の低下を示し，個々の例では 1 例に 於いて対照よりもやや高值を示したが推計学的にみ ると $\mathrm{F}_{\mathrm{s}}=27.08$ で Q02 の低下は危険率 1 \%以下で

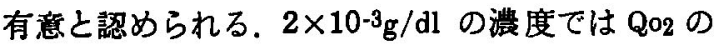
低下は少く2.096であり，2 例では増加が認められ ており，推計学的には $\mathrm{Fs}=0.16$ で有点の差はない。 毎10分酸萦消筫貫の㭙間的経過は四 5 亿示す如く $2 \times 10^{-1} \mathrm{~g} / \mathrm{d} 1$ の群で全般に著明に低下し他の例では 和り著明でなく，港加の初期之後期とでは殆んど差 を生じていない.
表 7 Prednisolone を添加した場合の正常 家兔骨酸の呼吸值

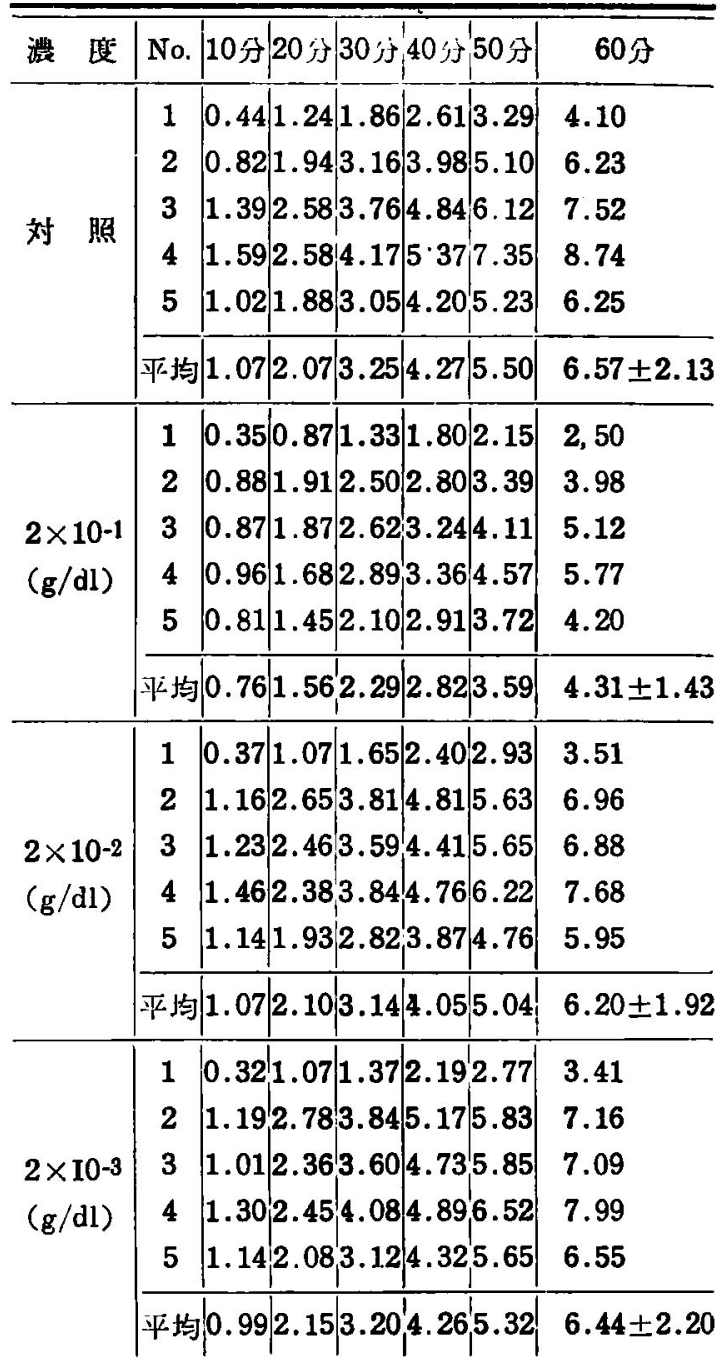

图 5 Prednisolone を添加した場合の每10分 酸素消貲量の時間的程過

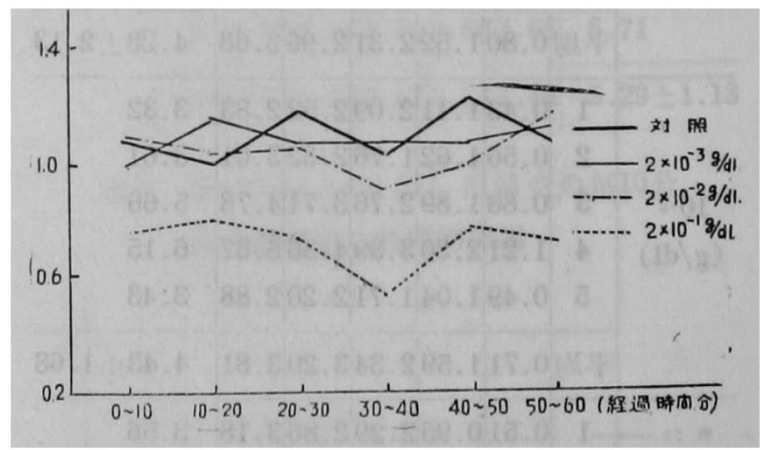

第 6 節 正常家兔骨随の呼吸値に及ぼす ACTH 添加の影㛺

表8 亿示す如く $2 \div 102$ unit/dl の濃度では Qo2の 平均值は対照に比し 8.5\% の艺進を示し，個々の例 では全例に於いて上型し，推計学的にみると $\mathrm{Fs}=$ 
表 8 ACTH を添加した場合の正常家鬼 骨䯣の呼吸值

\begin{tabular}{|c|c|c|c|}
\hline 清 度 & No. & 10 分20分 30 分40分50分 & 60 分 \\
\hline \multirow{6}{*}{ 対 照 } & & $0.441 .24 \mid 1.862 .613 .29$ & 4.10 \\
\hline & & 0.821 .943 .163 .985 .10 & 6.23 \\
\hline & & $1.392 .58 \mid 3.764 .846 .12$ & 7.52 \\
\hline & 4 & 1.592 .584 .175 .377 .35 & 8.74 \\
\hline & 5 & 1.021 .883 .054 .205 .23 & 6.25 \\
\hline & 平均 & 1.072 .073 .254 .275 .50 & $6.57 \pm 2.13$ \\
\hline \multirow{6}{*}{$\begin{array}{c}2 \times 10^{2} \\
\text { (unit/dl) }\end{array}$} & 1 & $|0.49| 1.30|2.07| 2.88|3.64|$ & 4.35 \\
\hline & 2 & 1.332 .524 .115 .045 .98 & 7.43 \\
\hline & 3 & 1.462 .703 .945 .186 .76 & 8.11 \\
\hline & 4 & $1.41 \mid 2.814 .405 .637 .74$ & 9.14 \\
\hline & 5 & $1.33|2.393 .324 .385 .71|$ & 6.63 \\
\hline & 平均 & $1.20|2.32| 3.57|4.625 .97|$ & $7.13 \pm 2.25$ \\
\hline \multirow{6}{*}{$\begin{array}{c}2 \times 10 \\
\text { (unit/dl) }\end{array}$} & & $0.44^{\prime} 1.362 .173 .053 .81$ & 4.67 \\
\hline & 2 & 1.282 .694 .105 .266 .28 & 7.70 \\
\hline & 3 & 1.432 .974 .295 .617 .25 & 8. 68 \\
\hline & 4 & 1.523 .054 .766 .108 .00 & 9.53 \\
\hline & 5 & 1.432 .573 .574 .726 .15 & 6.86 \\
\hline & 平均 & $1.222 .53 / 3.384 .956 .30$ & $7.09 \pm 2.17$ \\
\hline \multirow{6}{*}{$\begin{array}{c}2.0 \\
\text { (unit/dl) }\end{array}$} & 1 & $0.471 .422 .253 .083 .79 \mid$ & 4.68 \\
\hline & 2 & 1.872 .924 .335 .386 .44 & 7.02 \\
\hline & 3 & 1.302 .954 .735 .927 .80 & 9.85 \\
\hline & 4 & $1.44|3.124 .81| 6.028 .17 \mid$ & 9.85 \\
\hline & 5 & $1.64|2.14| 3.43|4.72| 6.00 \mid$ & 6.86 \\
\hline & & $|1.34| 2.51|3.91| 5.02\} 6.44 \mid$ & $7.65 \pm$ \\
\hline
\end{tabular}

11.26で $5 \%$ 以下の危険率で Q02 の元進は有意であ る. $2 \times .10$ unit/dl の濃度でも Q02 の平均值は対照 に比し，7.9\%高くなつており，全例に於いて艺進 しており推計学的にも $\mathrm{Fs}=71.85$ で他険率 1 名以 下で有意の差が認められた，2unit/dl の鋠度に於い

因 6 ACTH を添加した場合の住10分酸素消 量量の時間的経過

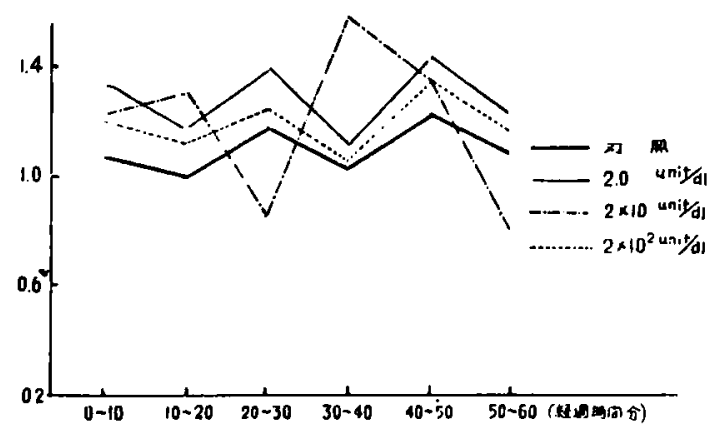

て6 Q02 の平均值は16.496增加しており, 全例之 あ增加が認められている。これを推計学的にみると $\mathrm{Fs}=270.11$ で 1 名以下の危険率で差は有志である。 毎10分酸素消費㟟の時間的経過は四 6 亿示す如くど の群むかなりの変動を示しているが，経過時間によ る差異は認められない。

第 7 節 正常家兔胃髓の呼吸值に及ほす Actinomycin C 添加の影響

表 9 に示す如く Q02 の平均侹は $2 \times 10^{-3} \mathrm{~g} / \mathrm{dl}$ の 濃度では1.796低下し $2 \times 10^{-4} \mathrm{~g} / \mathrm{dl}$ の漕度では 2.096 元進を示しているが個々の例では増加するむのや減 少するものがあり，推計学的にはそれぞ扎Fs= 0.29 及で $\mathrm{Fs}=0.22$ で有些の差は認め得ない. $2 \times$ $10.5 \mathrm{~g} / \mathrm{dl}$ の㳻度に於いては Q02 の平均值は6.796の 增加を示し，個々の例に於いて屯減少を示したもの は 1 例のみて，推計学的にみると $\mathrm{Fs}=16.76$ で

表 9 Actinomycin C を添加した場合の 正常家鬼骨䯣の呼呚值

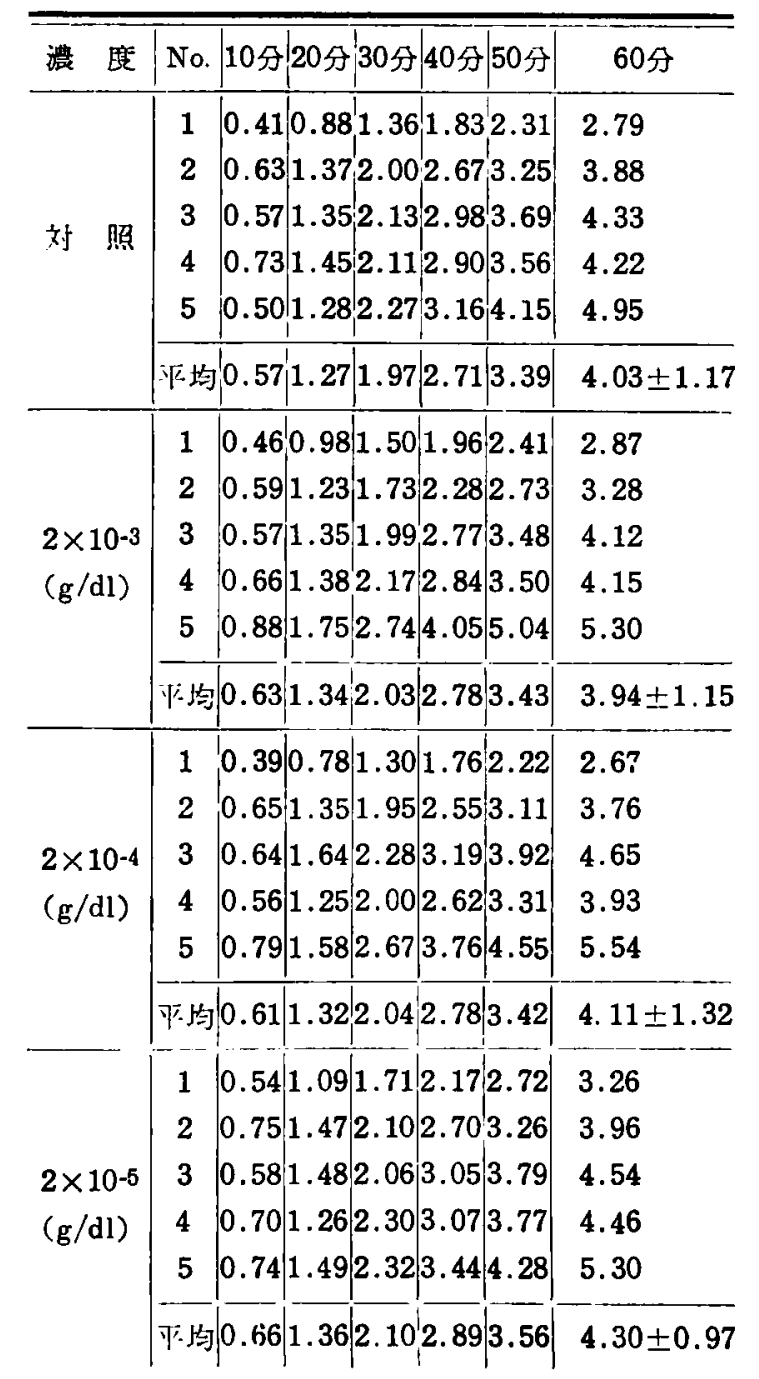


2.596以の危除率て Q02 の增加有染てある。每

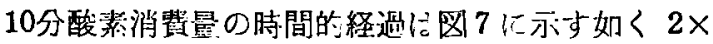
$10-3 \mathrm{~g} / \mathrm{dl}$ の濃度では経遇時間とともにやや減少の傾 向か認められるが低滥度のあのにあつては対照と略 ふ平行している.

[月 7 Actinomycin C を深加した版合の们10

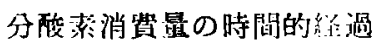

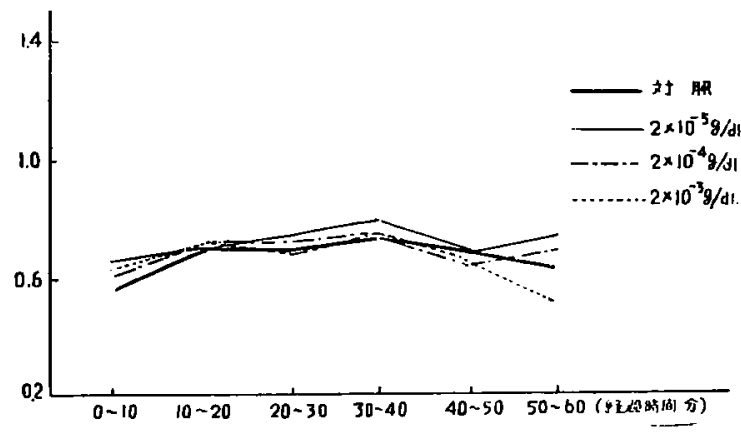

第 8 節 正常家禿骨㩆の呼吸佃に及ぼす Carzinophilin 添加の影簟

表10に示す如く $5 \times 10^{-4} \mathrm{unit} / \mathrm{dl}$ の湍度では Qo2 の平均值は対照に比し12.2\%の但下を示すが個々の 例については 1 例に増加を認めるすのがあり, 推計 学的には Fs=1.13て有壳といえない, $5 \times 10^{3} \mathrm{uni}$ / $/ \mathrm{dl}$ の䟴度では Q02 の平均值は11.7\%のの進を示して いるが，推計学的には Fs=4.00 でその差は有意と 隹涩められない. $5 \times 10^{2}$ unit/dl の濃度では対照と 殆んど差はなく勿論 推計兴的!も $\mathrm{Fs}=0.19$ で有志

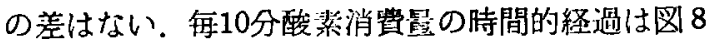
に示す如く，高浱度では㭙間の経過とともにQ。2

表10 Carzinophilin を添加した埸合の正

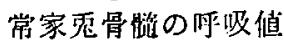

\begin{tabular}{|c|c|c|c|}
\hline 濃 度 & No. & 10 分 20 分 30 分 40 多 50 分 & 60 分 \\
\hline \multirow{6}{*}{ 対 照 } & 1 & $|0.41| 0.88|1.361 .83| 2.31 \mid$ & 2.79 \\
\hline & 2 & 0.631 .372 .002 .673 .25 & 3.88 \\
\hline & 3 & $0.57 \mid 1.352 .132 .983 .69$ & 4.33 \\
\hline & 4 & 0.731 .452 .112 .903 .56 & 4.22 \\
\hline & 5 & 0.501 .282 .273 .164 .15 & 4.95 \\
\hline & 平均 & $0.57|1.271 .97| 2.713 .39$ & $4.03 \pm 1.17$ \\
\hline \multirow{6}{*}{$\begin{array}{c}5 \times 104 \\
\text { (unit/dl) }\end{array}$} & 1 & $|0.44| 1.07|1.63| 2.002 .38 \mid$ & 2.70 \\
\hline & 2 & 0.851 .602 .102 .703 .16 & 3.66 \\
\hline & 3 & 0.821 .942 .653 .574 .29 & 5.00 \\
\hline & 4 & 0.791 .281 .952 .623 .04 & 3.47 \\
\hline & 5 & 0.500 .991 .582 .182 .37 & 2.87 \\
\hline & & $0.681 .38|1,98| 2.61|3.05|$ & $3.54 \pm 1.13$ \\
\hline
\end{tabular}

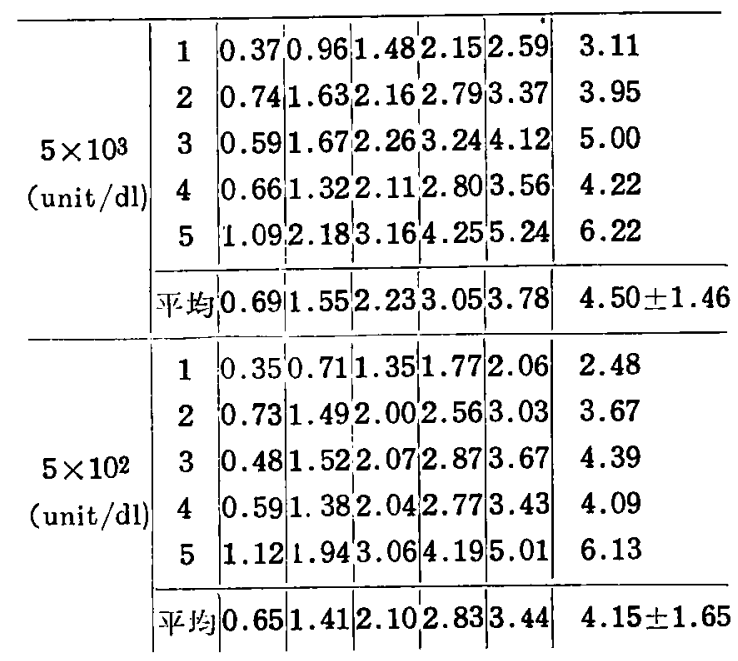

网 8 Carzinophilinを添加した埸合の每:10分 酸絜消整鼠の㭙間的経過

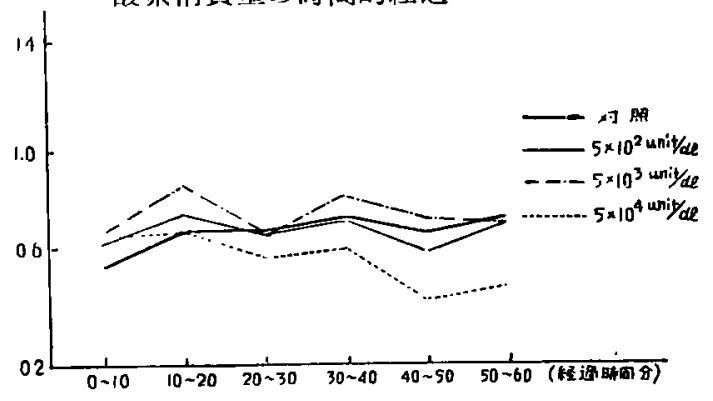

は漸次低下しているが，低䟴度では添加直後やや增 加し添加してから20分以後は対照と差を認めない.

第4章 総括並ひに考按

(1) Nitromに就いて

Nitromin は石舘102)，吉田によつてとりあげ られ，恧性腫曒の化学㳫法剂として広く用い ら扟ているか，正常の組織に対して角本等26)は 家鬼について睪丸，嘰，肝，腎，大脸皮質等の呼 吸を抑制することを報じ，島内20)等は骨骮顆 粒球の減少と骨璡細胞のMitochondria 減少と Qo2 の低下を観祭し，永井36）は Nitromin 投与家

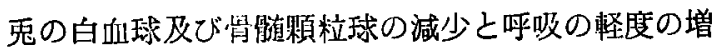

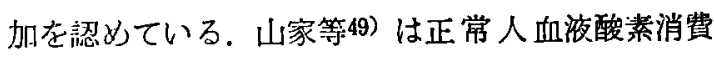
量が減少するといい赤沢1は正常人血液解糖值が低、 下ずると述べた，又姬野44）等及び内田7)，屯赤血 球の娍少と胃髄紏胞の減少を認めている，更に小 松15）は顆粈白血球の会喰能の低下を観察し，教室 角南23）は䟴度に比例した盟柆貪喰能の低下を認め ている. 以上の如く Nitromin は骨䯣をはじめ生体 組織細胞に対して障害的に作用することが認められ ているが，その作用機序に関しては細胞の増生に関 
与する蛋白及び䤃素，特に SH 系醉䒺阴害及び朴 酸代謝の障害か観察されており，清水 ${ }^{133)}$ は二十日 闵肝で Nitromin によるコリン酸化醋秦の阻害と コハク酸酸化䣼素の軽度の㧕制を認めており，又 DNA の粘度を著明に低下させることが, Gjessing87)， Butler ${ }^{71)}$, Goldacar (99), Ross $^{(26)}$, Biesle64)，原(196), Alexander55）等によつて報告せら㣗，石㗍3）によ つて有系分裂抑制作用有寸万ことか涊心られてい

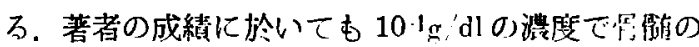

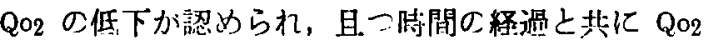
の低下は著明となつており，Nitromin が呼吸醇素

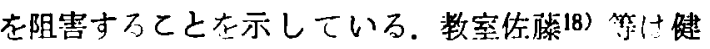

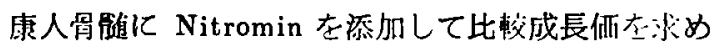
$0.5 \mathrm{~g}$ 'd $\mathrm{dl}$ では著明な低下を $0.05 \mathrm{~g}$ 'dl ては中等度の $0.005 \mathrm{~g}$ 'dl では軽度の低下をみており著者の成績と 略々承行しており Nitromin は直接骨䯠に作用して 代謝を抑制し造血機能を低下せしめるあのである。

(2) Myleran 汇就いて

Sulfonic ester 基を反応基として有する Alkylating agent である本剂は Haddow 等94)により顆 粒球を特に㧕制するととが述べられ，Galton86）に より慢性男随性白血病に卓效を奏することが報じら れたが，その作用は，Nitromin と略々同様である とされている。しかしその作用は極めて緩徐であり 副作用も一般に甚だ少い. Myleran の正常骨軻に 及ほす影響については佐藤(1) 等か人骨䯣に添加し て組綃培美を行い比輬成長価を算出し $2 \times 10^{-1} \mathrm{~g} / \mathrm{dl}$ 及び $2 \times 10^{-2} \mathrm{~g} / \mathrm{dl}$ で軽度の抑制を示し $2 \times 10^{-3} \mathrm{~g} / \mathrm{dl}$ では差がないと逵へているが，他に報告は見当らな い. 正常家克骨髄 Qo2 に対しては Mylerdn 添加 は $2 \times 10^{-2} \mathrm{~g} / \mathrm{dl} \sim 2 \times \cdot 10^{-4} \mathrm{~g} / \mathrm{dl}$ で有奆の差は認められ ず,これは添加後観察時間の短かいことにもよるて あろうが骨檤に対する作用が温和であることを示す おのであるといえよう。

(3) 8-Azaguanine に就いて

本剂は Purine 代謝の强力な阻管物斯であり，模代 謝において必須代謝物質である Guanine の拮抗体で ある. Kidder 等108) は Tetrahymenaを用いて発育阻 止実験を行い，8-Azaguanie が Guanine とよく拮 抗し，模蛋白代謝を阻害するととが明らかにせられ， 又哺乳動物の正常細胞ては Guanine と模酸の結合 能力は僅かであり，正常細胞の代的を障害せず，一方 腫瘍細胞に於いては Guanine 代謝能力を有するも のとして実験を行ない腫場の発育卯制を認めている。 長谷川等41) は吉田肉腫細胞を用い 8-Azaguanine を
添加して酸䋕消費量の低下を認めており，山元52)は

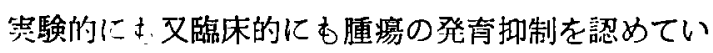
ろが造向䑏器に及ほす寸影響についてはふれておらず, 田坂32)18)等は血液像に著変を認力ないと報じている。 上述の如く正常細胞の Guanine 代謝能力が極めて

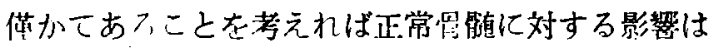
余りないけのと予想されるが，小松15）は家兔顆粒

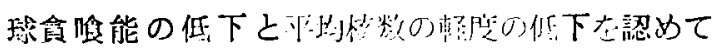

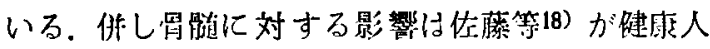

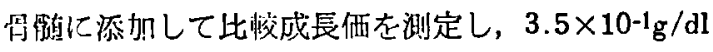

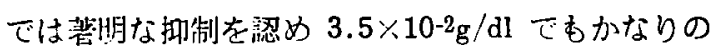
抑制を被めていろが，エネルギー代謝については観 察せられていない．著者の成績によれば 10-1 $\mathrm{g} / \mathrm{dl} 〜$ 10-3 g/dl の各峘度に於いて Qo2 は対照之有奆の差を 示さず直接骨随の呼吸作用に影響を与えないすのと 認められたが Guanine 代謝を抑制する本剤は造血 挠器に対する影蠁は大きくないものと考えられる。

(4) 6-Mercaptopurine 亿就いて

Adenine代謝を阻害する 6-Mercaptopurineは Burchenal等69)により急性白血病に対する効果が認めら れたが，以後広く白血病の治療剂として用いられて おり，副作用として造血機能の抑制が認められてい

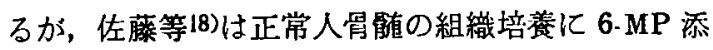
加を行ない比較成長価を求め $5 \times 10 \mathrm{~g} / \mathrm{dl}$ 及び $5 \mathrm{~g} / \mathrm{d} l$ で著明に抑制を認め $5 \times 10^{-1} \mathrm{~g} / \mathrm{d} l$ では殆んど差を 認めていない，一方永井37) は 6-MP 投与家鬼につ いて TCA 阻害物質と同様㳊骨䯠の Mitochondira 酸化が抑制され $\mathrm{P} \cdot \mathrm{O}$ 比か低下するととを報告し， 核酸代到を阻害する本剂はエネルギー産生系と密接 な関係を有することを認めているが著者は骨䯣に直 接添加した場合の呼吸作用について観察し， $5 \times$ $10^{-1} \mathrm{~g} / \mathrm{dl}$ 及び $5 \times 10^{-2} \mathrm{~g} / \mathrm{dl}$ の乑度に於いてQo2の低下 を認め，骨榷造血機能が抑制されることを確涊した。

(5) Prednisolone に就いて

Pearson118), Farber82), Dameshek ${ }^{76)}$, Rosentha1125)等により急性白血病に ACTH, Cortisone が 用いられて以来これら Hormone 剂は益々盛んに用 いられるようになり，更に効力のすぐれた副腎皮澌 Hormone が多数出現した. この中 Prednisolone は広く用いられており，著效をおさめているが，そ の作用機序に関しては，細胞の蛋白質代謝及び核酸 代謝に及は影響が考えられ，又呼吸解糖代謝に対 する影䪪も観察されている。.Kit109), Skipper ${ }^{134)}$, Kass 106)，は淋巴球の校酸代謝が副腎皮啠 Hormone により阳害されるこ゚とを羿め，Cavallero72）等は家 
鴊胎児の RNA 最を減少させるととを認めてい る.これに対し赤血球系に対しては Cortisone は 機能六進的に作用し副腎皮質不全はこの機能を低下 させるとの報告が Gordon 等90)，Bermann63) 等及 び野手40）によつてなされている。一方末梢血顆粒 球の領喰能は Cortisone 投与により低下するととが 小松14）により認められており，又佐藤等18）によ り健康人冏能道組織培羡に於いて Prednisolone は 10-1 g/dl で中等度の低下を認めているが，根岸39） は，胸腺，淋巴腺，脾臟の呼吸作用について Cortisone の影響を検討し呼吸值の低下を見ている が，とれに対し Gordon91) は副腎摘出動物では骨 骮括の解糖作用结增大し副堅皮質 Hormne を投与す ると正常值に復し，正常動物に投与すると解糖值は 低下するととを認めている。一方副骨皮質 Hormone は酸化代謝に関与する諸酵素に対しては，動 物の副腎を剔出するとコハク酸脱水秦酵素及び， $\alpha$ ケトグルタール酸、フマール酸、クエン酸等の酸化醉 素の活性が低下することが Tipton138)139), Russel127) 等, Bourne等68), Umbreit 142) によつて認められと の低下が Cortisone の投与により回復することが Mustakalliol14)等Umbreit142)によつて認められてい るが, Stucki(37)等 Bergen62) 等はこれと逆の結果 を得ている. 又 Sourkes and Henage ${ }^{136)}$ は Cortisone 投与によりクエン酸回路の代謝物質の酸化が著しく 低下することを報じている. 更に Cortisone は副腎 剔出によつて Cytochrom C, Cytochrom 酸化酻素 DPN の城少が起るととが Tipton140)，Drabkin79， Tipton141)等 Ringer and Leonard122) によつて認め られ, Cortisone で DPN が回復するととも認めら れている.との様に副堅皮質 Hormone は酸化酥素 及び助醉素の産生を增し代謝を方進せしめる如く作 用する報告が多いが一部てれに反する報告もありそ の作用機序に関しては充分明らかにされていない。 既述の如く組織細胞に直接副堅皮質 Hormone を添 加㧕制作用を認めた報告はあるが，骨髄の呼吸作用 に対する影辢については未だ検索せられていない。 著者の成績では Prednisolone は $2 \times 10-1 \mathrm{~g} / \mathrm{dl}$ の浱 度では著明にQ02 を低下せしめ $2 \times 10-2 \mathrm{~g} / \mathrm{dl}$ の浱 度においても軽度の抑制を示しており，小松14), Gordon91)，根岸39，佐藤18）等の成績と同様の傾向 を認めた。即ち Prednisolone は高濃度乃至中等濃 度で直接罪艏に作用して呼吸值を隇少せしめる作 用を有することが判明した。しかしこれが如何なる 機序によるものであるかは，ただ醭素活性その他に
影響を与えるととによるすのであろうことを予想し 得るのみで詳細に関しては全く不明である。

(6) АCTH に就いて

脳下垂体を摘出すると負血を来すことはよく知ら れ，Van Dyke144)145)146) 等は下垂体前葉に赤血球 系の造血を刺戟する Hormone の存在を認めたか， ACTH とは別に造血刺戟 Hormone か存すること が Van Dyke143)により明らかにされており ACTH はその骨髄赤血球系に対する直接作用はないと考え られつつある.これに対し ACTH の白血球系に対 する作用は，大藤助教授9は直接骨髄に添加して骨 髄の成熟細胞の機能をえ進せしめる結果を得ており 教室小林等13) は顆粒球娍少症骨髄に添加して組 織増生を著明ならしぬるととを明らかにし，野手40) は家鬼に ACTH を投与して30分後より偽好酸球增 加が起り 24時間で正常值にかえり再び増加すること を認め，初期の増加は，遊出，成熟の促進によるも のであり, 後期の増加は増殖, 成熟, 游出の伪好酸 球造血全般にわたる刺戟の結果であるとしている. 更に教室角南24)等は健康人及び特発生栓球減少症

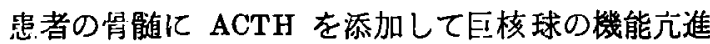
を認めている.この様に ACTH は好中球及び巨核 球機能を亢進せしめることが認められているが，淋 巴組織に対しては抑制的に作用し，根岸39）等は白 鼠の胸腺淋巴腺，脾の組織呼吸を低下させることを 報告している，ACTH の組織呼吸作用に及ぼす影 響についてはこの他吉田63）が試験管内で犬副監皮 質切片の酸素消費量を増加せしめることを諗めてお り，解糖作用については竹下3031）が正常家鬼血液に ついて六進を認めている. しかし骨娟に直接添加し て呼吸作用に及ぼす影響を検索した報告はない，著 者の成績によれてば, $2 \times 10^{2}$ unit/dl 乃至 2 unit/dl の 濃度において何れす酸素消䚉罢を増大せしめ，特に $2 \mathrm{unit} / \mathrm{dl}$ では增加は著明である. 即ち ACTH は 直接骨稙に作用して呼吸作用をえ進せしめ，このこ とは，上述の成績ともよく符合している．

(7) Actinomycin C に就いて

Hodgkin 氏病に対して使用せられている Actinomycin の骨髄に対する影響については山崎等60), 芝等19）によつて報告せられ，骨髄の低形成乃至骨 葡芽球, 前赤芽球, 細網細胞の一過性の減少加認め られている。芝132) は Actinomycin が肝, 脾, 淋 巴腺，肙髄等の細網内皮系に強く吸着されることを 実験的に明らかにしており，骨髄に対する抑制作用

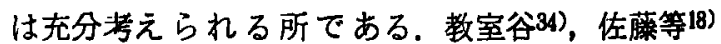


は正常家兔骨䯣培養に及ばす Actinomycin の影響 を観察し， $5 \times 10^{-3} \mathrm{~g} / \mathrm{dl}$ で軽度の 抑制を認めている。 然して骨鹃道の呼吸作用に対しては $5 \times 10^{-3} \mathrm{~g} / \mathrm{dl}$ 及び $5 \times 10^{-4} \mathrm{~g} / \mathrm{dl}$ の濃度では対照との間に差を示さず， $5 \times 10^{-5} \mathrm{~g} / \mathrm{d} 1$ の如き低濃度では却つて僅か一乍ら元進が 認められた。即ち呼吸代謝の面からは Actinomycin C は直接骨盏に障害的に作用するものではないと云 える。

(8) Carzinophilin に就いて

Carzinophilin は秦等98)汃Streptomyces Sahachiroi の培卷滤液から抽出した抗腫瘍性物質で，鎌田等104) により吉田肉腫に㧕制的に作用するととが知 られ，板垣103) は吉田肉腫勫胞の有系分裂を抑 制するととを認め，島田等21）により臨休的に用 いられ，その際末梢白血球数の減少を来すことが厚 々あることが報じられた．武石28)29）島田等21）は Carzinophilin 使用前後の骨檤像を検索し有校細胞 数，幼若細胞及び，成鶖顆煜球の著明な減少が起り， 休楽により回復することを明らかにした，又大久保 等115)は 1 回大量投与で家兔骨䯣赤芽球校分剖指数 を著明に低下させることを報告している，更に教室 谷34）は，正常家免骨檤組 織培盖に及ばす影響を観 察し, 比較成長価, 遊走速度, 墨粒領喰能は, 104unit/dl 以上の高漕度では明らかに抑制され， 103 unit/dl 以下の低濃度では軽度㧕制の傾向を認め ている.Carzinophilin の号榷呼吸作用に及ぼす影響 については報告に接しないが，武石28)29)，島田等21) の成績からは，呼忣作用の低下が予想される。しか し著者の実験ては $5 \times 10^{4}$ unit/dl 万至 $5 \times 10^{2}$ unit/dl

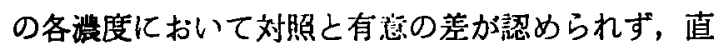

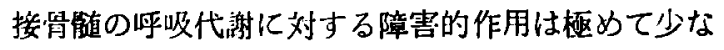
いものと考えられる.

\section{第5章 結 論}

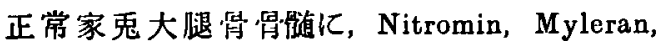

8-Azaguanine, 6-Mercaptopurine, Prednisolone, ACTH, Actinomycin C, Carzinophilin を直接添 加し呼吸作用に及ぼす影嚮を Warburg 検仼計によ り観察した結果次の如き成䀠を得た。

1） Nitromin は $10^{-1} \mathrm{~g} / \mathrm{dl}$ の濃度に於いて骨䯣の 呼吸作用を低下せしめ, 毎10分酸素消觜是は時間の 经過と共に渐次減少することが認められた。

2）Myleranは骨榷の呼吸作用に影響を及はさ ない.

3）8-Azaguanineは骨鹃道の呼吸作用に影響を及 ぼさない.

4) 6-Mercaptopurine は $5 \times 10^{-1} \mathrm{~g} / \mathrm{dl}$ 及び $5 \times$ $10-2 \mathrm{~g} / \mathrm{d} l$ の濃度に於いて置璡の呼吸作用を抑制する ことが認められた。

5) Prednisolone は $2 \% 10^{-1} \mathrm{~g} / \mathrm{dl}$ 及び $2 \times 10^{-2} \mathrm{~g} / \mathrm{d} l$

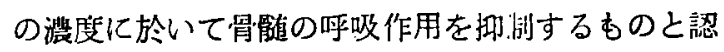
められた。

6) $\mathrm{ACTH}$ は $2 \times 10^{2} \mathrm{unit} / \mathrm{dl}, 2 \times 10 \mathrm{unit} / \mathrm{dl}$ 及び 2 unit/dl の各䟴度に於いて，骨置の呼吸作用を䒕 進せしめるものと認められた。

7) Actinomycin C $2 \times 10^{-5} \mathrm{~g} / \mathrm{dl}$ の濃度で骨 咀の呼吸作用を軽度に亢進せしめるものと認め，そ の他の漂度では，対照と差がなく骨檤の呼吸作用を 抑制しない。

8) Carzinophilin は骨䯣の呼吸作用を殆んど抑 制しないが $5 \times 10^{4}$ unit/dl の濃度に於いては毎10分 酸素消賈星は時間の経過と共にやや低下の傾向を 示した。

要するに Nitromin, 6-Mercaptopurine, Prednisolone は一定の濃度に於いて骨睢に直接作用して 代謝を卯劋し造血機能に影響を与えるものと考えら れ，ACTHは直接留盛の代謝を元進せしわ，造血機 能の促進へ導くものと考えられる.

\section{全 編 の 総 括}

第 1 絆及び第 2 編に於いては白血病の本態を代謝 譏能の面から究明しようと試み，骨能体体外組織培裳 により診断が確定せられた各種白血病患者に就いて

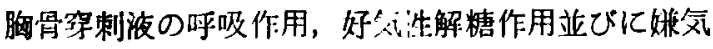
性解㶳作用を Warburg 検任計を用いて湘定し，末 悄赤血球の呼吸作用をむ併わせ観察し，白血病では 正常と異つた所見を呈すると共に病型によつても巠
異のあることを明らかにした。

胸胃穿制液 $0.2 \mathrm{cc}$ 当り 1 時間の酸素消費冒並びに

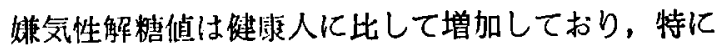
佛父性解糖值は呼吸值に比し著明に䒕進している。 その程度は病型により相違があり, 呼吸值と嫌気性 解糖倬の增加は平行的でなく，呼吸値は慢性骨䯣性 白血将に於いても急生白血病と略々同程度に穴進し 
ているが，嫌気性解楛値の增加は急性白血病沉比べ て可成り低い.

無脂肪乾燥重量 $(\mathrm{mg})$ 当りの 1 時間の骨周通呼吸 値並びに嫌気性解粘值屯白近病に於いては增师して おり，呼吸值を高いものから挙げると算球性白血病，

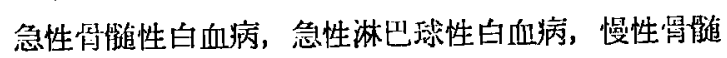
性白血病, 慢性淋已球性白血病の順となるが, 梆気 性解粕值では急性淋已球性白血病が最む高く，急性

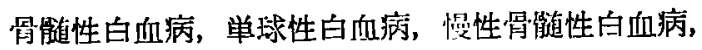
慢性淋巴球性白血病の順认なつており呼吸值と解糖 侐とは心ずしも平行していない，呼吸值と嫌気性解 糖值の比を見ると $Q_{\mathrm{NI}}^{\mathrm{No}} / \mathrm{Q} \mathrm{O} 2$ は急性淋巴球性白血病 及び急性骨䯣性白血病では健康人の約 2 倍に増加し ているが，慢性骨髄性白血病では煡康人よりやや大 きい程度に止まり，単泳性白血病では急性と慢性の 中間にあり, 本症の臨床症状, 血液所見, 骨骮体外 組織培羡所見が急性と慢生の中間的性格を有してい るのとよく符们している.

単位細胞当りの呼吸值並びに嫌気性解精値は病型 による差が著るしく，急性骨髄性白血病に於いて最 あ高く, 単球性白血病がてれに次ぎ, 慢性骨随性白 血病では正常值に近く，淋巴症性白向病では急性， 慢性之もに正常值に比し著るしく低い。

呼吸値及び嫌気性解糖值は冎链有校細胞数, 幻若 細胞百分率と或程度の平行関係を有しており, 又幼 若細胞百分率の增加と之もに単位細胞当りの梆気性

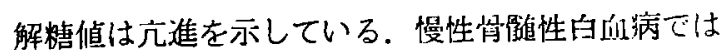
治療に上る寛解時汇は呼吸値，嫌気性解糖值とも低 下し，增悪時には亢進するが，この際にも嫌気性解 粘值の方が変動が大きい，要するに白血病では特に 媖気性解粠値の亢進が著明であるが，病型により程 玫の差があり単球性白血病では急性と慢性の中間的

文

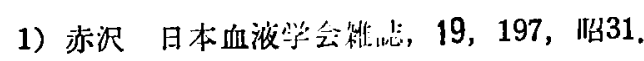

2) 尼子：医事新闻，1142，649，大13.

3）石館：澏の化学療法, 55 , 昭 32 .

4) 石橋: 風山医学会棑誌，69，740，明32.

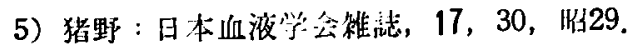

6)上㷧，国征：綡合医”，13，802，昭31.

7）内田 日本血液学会雑誌，18，248，昭30.

8）大藤 日本内科”产”公稚誌，43，925，昭 30 .

9）大藤 最新医学， $11 ， 652$, 沿 31 .

10）腾沼：日本内科学会䧴誌， $23 ， 1$, 昭 10.

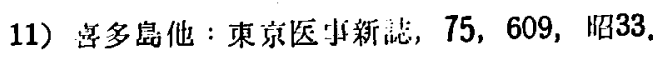

性格を有していることが代㴬面からあ朋らかになつ た，更に白血病全体沉就いては嫌気性解糖值の六進 は悪性腫堖に於ける程著明でなく，正常と悪性腫湯 の中間的性格を有しているといえる。

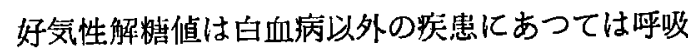
值の約 $80 \%$ 亿当たり白血病では多少の桨化は認めら れるが，その差は著明でなく白血病に特異な所見は なく代謝異常の指標とならない，白血病に於ける末 梢赤血球の呼吸㑤は慢性骨䯣性白血病に於いて正常 筑囲を示した他は健康人に比し軽度に低下しており 胃政造造赤血球機能が障害されているととを示してい る.

第 3 編に於いては各種抗白血病剂の正常胃酭に対 する直接効果を呼吸作用の面から検討し，Nitromin は $10^{-1} \mathrm{~g} / \mathrm{dl}$ の眼度で強く呼吸作用を低下せしめ, 時間の経過ととむに抑制効果は増強するととを認め ている. 6-Mercaptopuine は $5 \times 10^{-1} \mathrm{~g} / \mathrm{dl}$ 及び $5 \times$ $10^{-2} \mathrm{~g} / \mathrm{dl}$ の濃度で, Prednisolone は $2 \times 10^{-1} \mathrm{~g} / \mathrm{dl}$, $2 \times 10^{-2} \mathrm{~g} / \mathrm{dl}$ の溇度で呼吸作用を扣制することが明 らかになつた。 Myleran, 8-Azaguanine, Actinomycin C, Carzinophilin は骨檤の乎吸作用に対し て殆んど㧕制的に作用しないことを認めた。 ACTH は何れの濃度に於いても骨鹃道の呼吸作用を六進せし めることが認められた。

㨔算すると臨み終始御愁篗なる御指遒と御校閲の 桨を賜わつた恩師『木教授に衰心上り感謝の誠を捧 げると共飞御教示御援助を媔いた上原講師並びて国 歹博士に樑甚の謝意を表す。

本諭文の装旨は，第20四日本血液学会総会飞於い て器はした。

\section{献}

12）国处·阔山医学公雑被，67，59，昭30.

13）小恘他: 綜合隐床, 4, 1350, 沼30.

14）小松: 神戸医科大学紀要, 9，491，昭32.

15）小松：神可医科大学紌要，9，498，炤32.

16）小行 日本内科学会䊒衿，23，201, 昭10.

17）小吅綜合跍床，2，237，炤10。

18）佐藤他：東京医㩆新志，75，679，昭33.

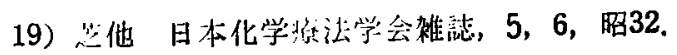

20）島内 日本血殷学会唯誌，16，270，昭28.

21）島时他：痤の化学桼法, 347 , 昭 32 .

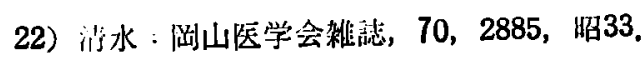


23）角南：政山医学会雑站，68，1169, 昭31.

24）角南他: 東京医事新誌，75，79, 昭33.

25）角本：京都府立医科大学经誌，8，299，昭 8 .

26）角本他：医療，7，15，昭28.

27）田口：臨床小児医学，4，43，昭31.

28）武石·日本化学療法学会雑誌，3，285, 昭30.

29）武石·日本化学療法学会椎誌，4，252, 昭31.

30) 竹下：生化学, 25, 45, 昭28.

31）竹下·東京医科大学雑誌，12，92, 略29.

32）田坂：瘦の化学㙩法, 308, 昭32.

33）館石：呼吸と循環，3，532, 昭30.

34）谷：岡山医学会雑誌，71，717, 昭34.

35）律田：内科仝函，2，18，昭30。

36) 永井.日本內科学会雑誌，43，822, 四 30 .

37）永井.日本血腹学会雑誌，21，393，炤33.

38）西内：棡山医学会雑誌，70，9, 昭33.

39) 根岸: 北関東医学, 3，229, 昭29.

40）野手 、日本臨床, 15, 1257, 昭32.

41）辰谷川他 日本血液学会㒕誌，20，247，昭32.

42）服部·臨床病理，2，276，炤30。

43）林 : 日本血液学会雑誌，2，351，昭13.

44）姫野他 . 日本血液学会雑誌，18，248，昭30.

45）平木：日本血液学会雑誌，19，406, 昭31.

46）平林：日本血液学会雑誌，2，286, 昭33.

47) 平木他：岡山医学会雑誌，70, 別巻，1，昭33.

48）藤田：医学生物学領域に於ける検圧法とその心 用, 昭 7 .

49）山家他：日本血液学会雉誌，19，196, 炤31.

50）山崎他：熊本医学公䧴鼔，30，892, 弨31.

51）山本：熊本医学会雑点，12，1477，㫟11.

52) 山元：虚の化学瘄法, 162, 沼32,

53）吉田：内分泌，2，546，䛇30.

54) Allegri, Ferrata Haematologica, 33, 317, 1949.

55) Alexander : Nature, 169, 572, 1952.

56) Arieff : Fol. Haemat., 45, 55, 1931.

57) Arinkin Fol. Haemat., 38, 233, 1929.

58) Bakker - Klin. Wschr., 1, 252, 1927.

59) Barron, Harrop : J. exp. Med., 48, 207, 1928.

60) Barron, Harrop . J. Biol. Chem., 84, 89, 1929.

61) Beck, Valentine . Cancer Res., 12, 818, 1952.

62) Bergen et al. . Am. J. Physiol., 171, 624,
1952.

63) Bermann et al. Endocrinology, 59, 656, 1956.

64) Biesle . Nature, 166, 1112, 1950.

65) Bird et al. ' Cancer, 4, 1009, 1951.

66) Bock et al. Klin. Wschr., 31, 816, 1953.

67) Bock, Felix . Z. exper. Med., 106, 235, 1940.

68) Bourne et al. . J. Physiol. 122, 178, 1953.

69) Burchenal et al. : Blood, 8, 965, 1953.

70) Bürger Z. ges. exp. Med., 31, 1, 1923.

71) Butler et al. . Canadian J. Res., 27, 927, 1949.

72) Cavallero . Proc. Soc. Exper. Biol. Med., 81, 619, 1952.

73) Daland, Glover, Schmitz . Arch. int. Med., 46, 46, 1930.

74) Daland, Isaacs J. Exp. Med., 46, 53, 1927.

75) Damble : Z. exper. Med., 86, 595, 1933.

76) Dameshek et al. . Bull. New Engl. Med. Center, 12, 11, 1950.

77) Denecke Z. exper. Med., 36, 179, 1923.

78) Deutsch, Wagenfeld : Dtsch. Arch. Kl. Med., 171, 73, 1931.

79) Drabkin . J. Biol. Chem., 182, 335, 1950.

80) Elion et al.: J. Biol Chem., 192, 505, 1951.

81) Ellion et al. : Cancer, 7, 801, 1954.

82) Farber : Proc. Clin. ACTH Conf., 1, 328, 1949.

83) Farber et al. : New Engl. J. Med., 238, 787, 1948.

84) Fleischman, Kubowitz - Biochem. Ztschr., 181, 395, 1927.

85) Fujita - Klin. Wschr., 1, 761, 1927.

86) Galton - Lancet, 264, 208, 1953.

87) Gjessing et al. : Cancer Res., 27, 599, 1946.

88) Glover et al.: Arch. int. Med', 45, 46, 1930.

89) Goldacar : Nature, 163, 667, 1949.

90) Gordon et al.: Endocrinology, 49, 497, 1951.

91) Gordon et al.: Recent Progress in Hormone Research, 10, 339, 1954.

92) Grafe . Dtsch. Arch. f. Kl. Med., 102, 406, 1911.

93) Hackmann : Z. f. Krebsforsch., 58, 607, 
1952.

94) Haddow et al. . Lancet, 264, 207, 1953.

95) Hall, Furth Cancer Res. 2, 411, 1942.

96) Harada . Nagoya J. Med. Sci., 14, 206, 1951.

97) Harrop . Arch. exp. Path. Pharm., 66, 71, 1911.

98) Hata et al. : J. Antibiotics Ser. A 7, 107, 1954.

99) Hitchings et al. : J. Biol. Chem. 183, 1, 1950.

100) Hitchings et al. · Ann. N. Y. Acad. Sci., 52. $1318,1950$.

101) Huff . J. Clin. Invest., 29, 104, 1950.

102) Ishidate et al. . Proc. Jap. Acad. 27, 493, 1951.

103) Itagaki - J. Antibiotics Ser. B, 10, 18, 1957.

104) Kamada et al. : J. Antibiotics Ser. A, 8, $189,1955$.

105) Karnofsky - Arch. Int. Med., 87, 477, 1951.

106) Kass : Fed. Proc., I1, 472, 1952.

107) Kempner . J. Clin. Invest. 18, 291, 1939.

108) Kidder et al.: Science, 109, 511, 1949.

109) Kit et al. : Endocrinology, 52, 1, 1953.

110) Lison - Histochemie et cytochimie animales, 1953.

111) Lissaur : Klin. Wschr., 2, 403, 1865.

112) Mac Lean, Weir . Biochem. J., 9, 412, 1915.

113) Morawitz, Itami : Dtsch. Arch. Kl. Med., 100, 191, 1910.

114) Mustakallio : Ann. Med. Exper. Biol. Fenniae, 32, 297, 1954.

115) Okubo et al. : J. Antibiotics Ser. B, 9, $250,1956$.

116) Orr. Stickland Biochem. J., 32, 567, 1938.

117) Paterson et al. : Lancet, 1, 677, 1946.

118) Pearson et al. . Bull. N. Y. Acad., 26, 235, 1950.

119) Pflüger Pflüger's Archiv, 10, 251, 1875.

120) Pirwitz · Arch. exp. Path. Pharm., 207, 594, 1949 .

121) Remmele : Acta haemat., 13, 103, 1955.
122) Ringer, Leonard . Endocrinology, 55, 363, 1954.

123) Roessingh : Dtsch. Arch. Kl. Med., 138, $367,1922$.

124) Rona, Aranheim : Biochem. Ztschr., 48, 35, 1913.

125) Rosenthal et al.: Blood, 6, 804, 1951.

126) Ross Nature, 165, 808, 1950.

127) Russel et al. : J . Biol. Chem., 137, 713, 1941.

128) Schlossmann · Biochem. Z., 219, 463, 1930.

129) Schmitz, Glover : J. Biol. Chem., 74, 761, 1927.

130) Schretzenmayr, Bröcheler : Klin. Wschr., 15, 998, 1936

131) Shay et al. Arch. Int. Med., 92, 628, 1953.

132) Shiba Med. J. Osaka Univ., 7, 941, 1957.

133) Shimizu Nagoya J.Med. Sci., 15, 159, 1952.

134) Skipper et al.: Cancer Res., 11, 145, 1951.

135) Soffer, Wintrobe J. Clin. Invest., 11, 661,1932

136) Sourkes, Henage . Endocrinology, 49, 601, 1951.

137) Stucki et al.: J. Cell. Comp. Physiol., 40, 169, 1952.

138) Tipton Proc. Soc. Exper. Biol. Med', 45, $596,1940$.

139) Tipton: Am. J.Physiol., 132, 74, 1941.

140) Tipton . Endocrinology, 34, 181, 1944.

141) Tipton et al. : Am. J. Physiol., 145, 693, 1945.

142) Umbreit · Ann. N. Y. Acad. Sci., 54, 569, 1951.

143) Van Dyke . Blood, 12, 539, 1957.

144) Van Dyke et al. Blood, 7, 1017, 1952.

145) Van Dyke et al. . Proc. Soc. Exp. Biol. Med., 81, 574, 1952.

146) Van Dyke et al. : Acta haemat., 11, 204, 1954.

147) Victor, Potter . Brit. J. Exper. Path., 19, 227, 1938.

148) Warburg : Z. phsyik. Chem., 59, 112, 1909.

149) Warburg . Science, 123, 309, 1956. 
150) Warren : Am. J. Physiol., 110, 61, 1934.

152) Warren : Am. J. Physiol., 131, 176, 1940.

151) Warren : Am. J. Physiol., 128, 455, 1940.

153) Warren : Am. J. Physiol., 139, 719, 1943.

\title{
Studies on the Oxygen Consumption and Glycolytis of Bone Marrow
}

\section{Part 3. The Effects of Antileukemic Agents on the Oxygen Consumption of Rabbit Bone Marrow}

\author{
By \\ Hiroshi Sanada \\ Department of Internal Medicine Okayama University Medical School \\ (Director : Prof. Kiyoshi Hiraki)
}

With Warburg's apparatus the author studied the effects of the addition of various antileukemic agents such as nitromin, myleran, 8-azaguanine, 6-mercapurine, prednisolone, ACTH, actinomycin C, and carzinophilin directly to the bone marrow of the femur of normal rabbits, and obtained the following results.

1. Nitromin at the concentration of $10^{-1} \mathrm{~g} / \mathrm{dl}$ seems to inhibit the respiration of the bone marrow, and the oxygen consumption every 10 minutes decreases along with laps of the time.

2. Myleran has no effect on the respiration of the bone marrow.

3. 8-azaguanine has likewise no effect on thc respiration of the bone marrow.

4. 6-mereaptopurine at the concentrations of $5 \times 10^{-1} \mathrm{~g} / \mathrm{dl}$ and $5 \times 10^{-2} \mathrm{~g} / \mathrm{dl}$ seems to inhibit the respiration of the bone marrow.

5. Prednisolone at the concentrations of $2 \times 10^{-1} \mathrm{~g} / \mathrm{dl}$ and $2 \times 10^{-2} \mathrm{~g} / \mathrm{dl}$ seems to inhibit the respiration of the bone marrow.

6. ACTH at the concentrations of $2 \times 10^{-2} \mathrm{unit} / \mathrm{dl}, 2 \times 10 \mathrm{unit} / \mathrm{dl}$ and 2 unit/dl seems to accelerate the respiration of the bone marrow.

7. Actinomycin $\mathrm{C}$ at the concentration of $2 \times 10^{-5} \mathrm{~g} / \mathrm{dl}$ accelerates the respiration of the bone marrow slightly, but in any other concentration it does not differ from that of the control, suggesting that it does not inhibit the respiration of the bone marrow,

8. Carzinophilin hardly inhibits the respiration of the bone marrow, but at the concentration of $5 \times 10^{-4} \mathrm{unit} / \mathrm{dl}$ every ten minutes the oxygen consumption somewhat tends to decrease along with lapse of the time.

From these it is assumed that nitromin, 6-mercaptopurine and prednisolone at a specific concentration act directly on the bone marrow and inhibit its respiration, but ACTH directly accelerates the respirstion of tis buse murcow and tius enhançs the hematopoietic fucntion. 